ISSN 2338-4778 (Print)

Issued by English study program of IAIN Palopo

ISSN 2548-4129 (Online)

Volume 7, Number 1, June 2019

pp. $154-163$

\title{
Teaching English Vocabulary Through Think Talk Write Method
}

\author{
Amalia Yahya \\ amyatadju@gmail.com \\ Institut Agama Islam Negeri Palopo \\ Received : 9 Maret 2019; Accepted : 10 Mei 2019 \\ URL : http://ejournal.iainpalopo.ac.id/index.php/ideas
}

\begin{abstract}
The research focused on the use of think talk write method developing students' English vocabulary at the eighth year students SMP Datuk Sulaeman Putri Palopo. The research problem is that: does think talk write method effectively develop students' vocabulary at the students of SMP Datuk Sulaeman Putri Palopo? . The population of this research is the eighth year students of SMP Datuk Sulaeman Putri Palopo. consists of 120 students. In this research, the researcher used vocabulary test to assess and examine the students' writing vocabulary. The test are pre-test and post-test. The researcher collected data by using vocabulary test. The result of this research shows that there is significant development on students' vocabulary at the eighth year students of SMP Datuk Sulaeman Putri Palopo after conducting the treatment by using think talk write method. In which of $t_{\text {count }}(26.544)$ is bigger than the score of $t_{\text {table }}(2.048)$. it means that think talk write method gives significant contribution towards students' vocabulary development.
\end{abstract}

Keywords: Think Talk Write Method, Vocabulary

\section{Introduction}

One of strategy which is suitable in teaching vocabulary is think-talk-write (TTW). Think-talk-write (TTW) starting with thinking through reading, the result of reading is communicate through presentation, discussion, and making note about the result of discussion. There some activities students do in think-talk-write (TTW). The think-talk-write strategy builds in time for thought and reflection and for the organization of ides and the testing of those ideas before students are expected to write. The flow of communication progresses from student engaging in thought or reflective dialogue with themselves, to talking and sharing ideas with one another, to writing (Andriani, 2008). 
Amalia Yahya:

\section{The Effectiveness Students' English Vocabulary Through Think Talk Write Method}

Thinking and talking are important steps in the process of bringing meaning into student's writing. Classroom opportunities for talking enable students to connect the language they know from their own personal experiences and backgrounds with their vocabulary. Talking encourages the exploration of words and the testing of ideas. Talking promotes understanding. When students are given numerous opportunities to talk, the meaning that is constructed finds its way into students' writing, and the writing further contributes to the construction of meaning. Writing can help students make their tacit knowledge and thoughts more explicit so that they can look at, and reflect on, their knowledge and thoughts. So, the researcher conclude that this strategy suitable in teaching vocabulary, especially in vocabulary in a descriptive text.

The reason that the researcher applies think-talk-write (TTW) method in developing students' English vocabulary are (1) to create new styles of teaching rather than old fashioned direct instruction. (2) The researcher assumes that the students can encourage, and they can enjoy with many activities in think, talk, write method. (3) Activities in learning process contain motivational aspects and will increase the interesting in learning.

In reality, in daily classroom activity, student often find difficulty in vocabulary and how to differentiate those vocabulary. At junior high school grade in eighth year less knowledge of vocabulary.. In teaching learning process faces many problems, for example, when the teacher explained some topic, some of student look bored, annoying their friend, they can't keep silent, etc. So, word grouping activity is one of way stressful, more relaxed, and more enjoyable.

Based on the researcher's observation, it was found that the students face some problems in vocabulary. When the researcher asked the students of the eight year of SMP Datuk Sulaeman Putri Palopo. to translate some vocabulary, some of them cannot answers the questions. The students state that they don't really enjoy the method applied in their class. It is because the learning vocabulary was monotonous. And the other problems were the students have low motivation and were not interested in memorizing vocabulary. Usually the students were taught by the teacher without being given appropriate method, appropriate technique and interesting media in learning vocabulary.

Basically, there are many method and ways to teach vocabulary effectively. However, the researcher just uses think talk write method. It is believed that through think talk write method, the students will be easy to understand and interested to learn vocabulary.

This method is reasonable to be applied at the students of junior high school especially in SMP Datuk Sulaeman Putri Palopo. because many students less understand mastered of vocabulary. The researcher believes that the problems are influenced by many factors such as student's lack of vocabulary, shy to speak, lazy to practice or students don't know what they want to say. But in this cases though think talk write method recognized to reveal students problem in the effectiveness their English vocabulary. It is important to teach vocabulary since in can influence the communication skills. When people could master grammar and Pronunciation better than vocabulary, they will be difficult to communicate but if their master vocabulary is better than grammar and Pronunciation they will be easy to communicate (Widya,1997)

Based on the background above, the researcher interested in carrying out an experiment research entitled "Teaching Vocabulary through Think Talk Write Method" at the Eight Year Students of SMP Datuk Sulaeman Putri Palopo. In line with background of study, the main purpose of this study is to find an effective method in developing English vocabulary. So, the formulated research problem is that "Does Think-Talk-Write method effectivelly develop students' vocabulary at the students of SMP Datuk Sulaeman Putri Palopo.?".

The objective of this research is to find out whether or not the think - talk - write method effective to facilitating the students' vocabulary skills of the eighth year students at SMP Datuk Sulaeman Putri Palopo..

The finding of the research is expected to provide contribution and recommendation in 
identifying some problems faced by the English teachers in teaching English, especially in English writing ability. It is expected to motivate students in learning English and the result of the study are expected to give contribution for English teacher, student, school, vocabulary and next research.

\section{REVIEW OF RELATED LITERATURE}

Penny Ur (1999) defines vocabulary: it is as the words we teach in the foreign language however a new item of vocabulary may be more than a single word. In another view Jhon read comment out that vocabulary is a list of words, sometime phrase, usually arrange in alphabetical order and defines as a dictionary, glossary, or lexicon some words may be recognized by some people but not necessarily. (Read, 2000)

While according to Martin Manser (1980) in his dictionary oxford learner's pocket dictionary, that vocabulary is all the words that a person knows or uses: all the words in a language; list of words that a person knows or uses: all the words with their meanings especially in a book a foreign language.

After seeing some definition of vocabulary above the researcher concludes that vocabulary is a list of words or phrases of a language that has a meaning and function in a language which is used of person to communicate with the other person.

Zulkarnaini (2011:82) states that Think-Talk-Write Strategy is facilitating the exercise of the language both oral and written fluently. This strategy based on the interpretation that learning is a social action. Think-talk-write (TTW) strategy encourages the students to think, talk, and write based on the particular topic. Think-Talk-Write strategy is used to develop the writing fluently and exercise the language before write them. Huinker and Laughlin, say that, think-talk-write strategy builds in time for thought and reflection and for the organization of ideas and the testing of those ideas before students are expected to write. Think-Talk-Write (TTW) is one of learning strategy which is purpose to improve student" understanding ability said Martinis Yasmin (2008).

Based on Yasmin and Ansari states this is the steps of Think-Talk-Write (TTW):

a. Students reading a text and make notes about what they have read (Think), then discuss with their group.

b. The students do interaction and collaboration with their group to discuss the notes (Talk). In this activity. The students using their own words to explain ideas in their group.

c. The students express the result of discussion in form written text (Write). Writing can help the students realize one of learning purpose and measure students understanding the material have learned.

d. The last learning activity is make a reflection and conclusion about what they have learned. One of the students from each group presentation their answers, while other group give an idea. ${ }^{1}$

On this strategy, had some step for implementation, that are:

The first step is THINK. Think is a vocabulary that the students read a text (a theme/material). In this vocabulary the students should think possibility the answer, and the students make a little script about ideas that obtained on the text. The second step is TALK. Talk is an activity that certain make a discussion with their friends in a group. In there the students should to sharing the idea that was had at the think step. And make a reached with the groups. The third/ last step is WRITE. In this vocabulary the students appreciation their ideas to an essay about the material that was been given. Write is an activity of all brains that make the right (emotional) and the left (logic) of brains. A good essay make all of brains.

The students give a theme or some material. And the researcher asks to the students for thinking about this theme vocabulary. The second step is talk. In there the researcher devides the students in the class to some groups.

One group composes from four until five students. We ask to students to discussion with their friends in the groups. And the last step is write. We ask to students to write the result from 
Amalia Yahya:

\section{The Effectiveness Students' English Vocabulary Through Think Talk Write Method}

their discussion.

\section{Method}

In this research, the researcher applied a pre-experimental research method. It aimed to know "the student's vocabulary developing through think talk write method". Design in this research was one group pretest-posttest design. This research involved one class of students with pre-test, treatment and post-test design. This design of research can be described as follows:

\begin{tabular}{|c|c|c|}
\hline Pre - test & $\begin{array}{c}\text { Independent variable } \\
\text { treatment }\end{array}$ & Post - test \\
\hline $\mathrm{O}_{1}$ & $\mathrm{X}$ & $\mathrm{O}_{2}$ \\
\hline
\end{tabular}

This research involved two variables, such as dependent variable and independent variable. The dependent variable is the students' writing vocabulary and independent variable is write method vocabulary. The population of this research is the students at the eighth year of SMP Datuk Sulaeman Putri Palopo.that consists of number of the population are \pm 120 students who are consist of 4 classes. This research used purposive sampling. The researcher took VIII.b class as the sample, the number of sample were 30 students, all of the students at class VIII.b have a good participation and easy to understand with the lesson so that is way the researcher chooses class VIII.b as research object.

The researcher used vocabulary test to assess and examine the students' writing vocabulary ability. The tests are pre-test and post-test. The pre-test is given to assess and to examine the students' vocabulary ability by write the meaning of vocabulary in Indonesian or English based the test in the previous treatment while post-test is given after treatment of applying vocabulary through write the meaning of vocabulary in Indonesian or English as the manner to asses and examine the students' writing vocabulary ability. Both pre-test and post-test are used to find out the development of the students' vocabulary ability after the treatment by using vocabulary test.

The data was collected by using the procedures as follow:

\section{Giving Pre-test}

Before doing the treatment, the students were given pre-test to know their achievement in vocabulary. In this pre-test, the researcher asked the students to do answer the every vocabulary, in the test there are the Indonesian and English vocabulary. The test untill 30 about the noun, verb and adjective vocabulary. The students used 45 minutes.

\section{Giving Treatment}

After giving the pre-test, the students gave treatment for some meetings by applying Think Talk Write (TTW).

The treatment was conducted in four meetings:

the writer taught vocabulary by using think talk write method by using the following steps:

a) Teacher will asked to the students about noun.

b) Teacher asked to the students to gave example and write in whiteboard to noun vocabulary.

c) The teacher divided the students in some small group.

d) The teacher gave the reading text every group.

e) The students reading the text and make notes about what they have read (think is a vocabulary that the students read a text/material).

f) The students write. In this vocabulary the students appreciation their ideas about the material that was given, so from this activity the students can make the classification noun, verb and adjective from the text. 
g) The last learning activity is make a reflection and conclusion about what they have learned. One of the students from each group presentation their answers, while other group give an idea.

h) Do the discussion about noun from the text.

i) The teacher explained noun especially.

j) The teacher tried to play the think talk write and especially to noun vocabulary.

k) All of the students tried to answer without see the vocabulary which is given.

1) Teacher asked the students difficulties as long as teaching learning process.

m) Teacher gave conclusion about material.

\section{Giving Post-test}

After pre-test and treatment, the post-test was conducted to find out the students' vocabulary achievement after the treatment. It used to check the result of treatments;.

In this research, the researcher analyzed the data that had been collected from the sample by using following techniques.

1. Scoring the students answer from the vocabulary test that was given

$$
\text { Score }=\frac{\text { Total correct answer }}{\text { Total test items }} \times 100
$$

2. Classifying the students' score into the following classification:
a) $9,5-10=$ Excellent
b) $8,6-9,5=$ Very good
c) $7,6-8,5=$ Good
d) $6,6-7,5=$ Fairly good
e) $5,6-6,5=$ Fairly
f) $3,6-5,5=$ Fairly poor
g) $0-3,5=$ poor

3. Calculating the rate percentage of students score by using the following formula as follow:

$$
\mathrm{P}=\frac{F}{N} \times 100 \%
$$

Where: $\mathrm{P}=$ Percentage

$\mathrm{F}=$ the cumulative frequency of subjects

$\mathrm{N}=$ total number of subjects

4. In determining the means score, standard deviation, test of significance and standard significance. The researcher calculated it by using significance $t$ test to measure the effectiveness of think talk write in teaching vocabulary.

\section{Results}

The mean score of the students in pre-test were 10.38 and the mean score of the students in post-test were 22.03. The result of the table above shows that the mean score of students in post-test was higher than the mean score of students in pre-test. In addition, based on the statistical test result, it shows that $t_{\text {count }}\left(t_{0}\right)$ with the value (26.544) was higher that $t_{\text {table }}\left(t_{t}\right)$ with the value (2.048) with degree of freedom $(\mathrm{df})=28$ and on the level 0.05 . It means that there was a significant difference between the result of post-test.

Table of the t-test of the students

\begin{tabular}{|c|c|c|}
\hline Variable & $\mathrm{t}_{\text {count }}\left(\mathrm{t}_{0}\right)$ & $\mathrm{t}_{\text {table }}\left(\mathrm{t}_{\mathrm{t}}\right)$ \\
\hline $\mathrm{X} 1-\mathrm{X} 2$ & 26.544 & 2.048 \\
\hline
\end{tabular}


Amalia Yahya:

\section{The Effectiveness Students' English Vocabulary Through Think Talk Write Method}

The table of $t_{\text {test }}$ shows that the value of $t_{0}$ was higher than $t_{t}$, It can be conclude that the research hypothesis was confirmed. This is indicating that applying Think Talk Write gives good contribution to English teacher in teaching their students especially vocabulary The students enjoyed getting material and the situation of classroom to be good and fun. The students also participated actively in learning process continuing and the students competed to remember the vocabulary after giving treatment Think Talk Write. The writer recommends that the teacher should try to apply Think Talk Write when they want to teach the students.

In addition, Think Talk Write can develop the ability of students after treatment. The problem of students can be solved especially their vocabulary mastery. During the teaching with think talk write method, the students competed to remember the vocabulary after treatment in teaching process. This is in line with the previous research who states that Think-Talk-Write Strategy is facilitating the exercise of the language both oral and written fluently (Zulkarnaini, 2011:82). Furthermore, Think Talk Write method can give a better effect towards students' vocabulary. It could be seen in the result of the students' mean score and standard deviation after treatment of post test. It was proven that Think Talk Write method was effective in develop the students' English vocabulary.

From the respondents' vocabulary skill in post-test, it can be concluded that there is improving of the student's vocabulary. Finally, in comparing the result of $t_{\text {count }}$ and $t_{\text {table }}$, the researcher found that the value of $t_{\text {count }}$ was higher than $t_{\text {table }}, t_{0}>t_{t}(26.544>2.048)$. It means that there was significance difference between the result of pre-test and the result of post-test.

\section{Conclusion}

Think Talk Write is effective to develop the students' English vocabulary at the students of SMP Datuk Sulaeman Putri Palopo.. The students' result in pre-test with mean score 10.38 and post test of mean score 22.03. There is a significant difference between score before and after treatment Think Talk Write.

It can be proven by the students' result in pre-test and post test with showing that score $t_{t} 2.048$ and score $t_{o} 26.544$, Its mean that Null Hypothesis is rejected while the Alternative Hypothesis is accepted and the other word that Think Talk Write is effective to develop students' English vocabulary.

\section{References}

Ali Muhammad Subkhan, The Implementation of Think Talk Write (TTW) in Teaching Writing to $X^{\text {th }}$ Grade Students at SMAN 1 Ngawen Blora Academic Year 2015-2016. (Thesis S1: Universitas Nusantara PGRI Kediri), Unpublished. 2015.

Arikunto, Suharsimi, Prosedur Penelitian Suatu Pendekatan Praktek. Jakarta : Bina Aksara. 1999.

Arikunto, Suharsimi, Presedur Penelitian. Jakarta: PT Rineka Cipta. 2002.

Arikunto, Suharsimi, Presedur Penelitian : Suatu Pendekatan Baru Dalam Teori Dan Praktek. Jakarta : PT Rineka Cipta. 1992.

Asmur, Achievent on Vocabulary of the Second Year Students of SLTP Negeri 3 Anggareja Enrekang, Thesis S1. (Pare-Pare : IKIP UNISMUH) 2003.

Ag. Bambang. Setiadi, Learning English as Foreign Language. Jakarta : Graha Ilmu. 2006.

Bryant In Renee, Assessing Vocabulary, Carambrige University.2003. 
Fowle and Clyde, Vocabulary Notebook Implementation and Outcome, New York : Oxford University. 2002.

Harmer, Jeremy, The Praktice of English Language. New York : Longman. 1992.

Jane Wills, Teaching Vocabulary Through English, USA : Longman. 1981.

Henriksen, B, Three Dimensions of Vocabulary development. Studies in Second Languange Acguestion, 1999.

John, Read, Teaching Foreign-Language Skills. Second Edition, (Chicago and London: United States of America), 2000.

Journal Research, Ingrid Laurensia Simanungkalit and Sortha Silitonga, The Effect of Applying Think Talk Write Strategy on Students'Achievement in Writing Spoof Text. Unpublished.

Locky and Jhon Paul, Maximizing Vocabulary Development by Sistematically Using a Depth of Lexical Procesing Taxonomy and Effective Strategies, Seinam Women's University. 2002.

Liana Pratika Maizal Hartini, The Master of English Vocabulary of the Fifth Grade Students of SD 1 Padurenan Gebog Kudus in Academic Year 2011-2012 Taught by Using Think Talk Write Strategy, Thesis S1 : University Muria Kudus. 2012.

Michael J.W, Teaching Vocabulary, Oxford : English Language Book Sosiaty. 1982.

Maritis Yasmin and Ansari Bansu I, Taktik Mengembangkan Kemampuan Individual Siswa, Jakarta : Gaung Persada. 2008

M. Subana. Et. Al., Statistik Pendidikan,. Cet. I : Bandung CV Pustaka Setia, 2000.

Nation, Learning Vocabulary in Another Language, Cambridge : University. 1992.

Pieter A Napa, Vocabulary Depelopment Skills, Yogyakarta : Kanisius. 1991.

Penny Ur. Methodology in Language Teaching, United state of America: Cambridge University Press, 1999.

Tigor Hutapa, Statistik : Teori dan Aplikasi. Bandung. Cet I : STIE-IBEK. 1995.

Widya. Master Vocabulary is Better Than Grammar and Pronounciation, 1997.

Wilga M.Rivers, Teaching Foreign-Language Skill,(Second Edition; London: The University of Chocago Press, 1981.

Westfall, Tanja, Language Learning Strategies. 2005.

Yamin, M. 2008. Taktik Mengembangkan Kemampuan Individual Siswa. Jakarta : Gaung Persada Press. 2012.

Zulkarnaini, Model Kooperatif Tipe Think Talk Write (TTW) Untuk Menigkatkan Kemampuan Menulis karangan Deskripsi dan Berpikir Kritis. Unpublished Universitas Pendidikan. 2011. 